\title{
Chapter 7 \\ Empirical Analysis on the System Revisions of Judicial Real Estate Auctions: Comparison with General Real Estate Trading
}

\author{
Yusuke Ooka
}

\begin{abstract}
This paper shows the effect of a series of system revisions of judicial real estate auction in the 2000s on three factors: bid acceptance ratio, number of bidders, and highest bid. Using multiyear data of auctions from multiple district courts, I estimate the improvement of the three factors by the revision.

Furthermore, comparing real estate auction data with voluntary sale and general real estate trading data, I find that the selling price in auction was greatly lower than the price in voluntary sale even after the system revisions. Based on the empirical results, I suggest about necessity of further system revisions.
\end{abstract}

Keywords Auction - Real estate $\cdot$ Ordinary least squares regression analysis $\cdot$ Probit analysis

\subsection{Introduction}

It is said that selling prices for judicial real estate auction transactions are kept lower than trades in the general real estate market due to system distortions such as the restriction on free browsing of property interiors. To address this, the judicial real estate auction system has been subject to multiple system revisions in the 2000s. The ability to sell at a high price in the judicial real estate auction would not only be beneficial for the creditor but also for the debtor. In addition, active provision of property information is also desirable for purchasers. Furthermore, reducing a creditor's collateral risk and providing lower cost funding will also lead to lower interest rates and increased lending volumes in the financial markets thereby stimulating the entire economy. This paper focuses on the impact of the system revisions of judicial real estate auctions. Empirical analysis was conducted on the impact of

Y. Ooka (四)

Japan Housing Finance Agency, Tokyo, Japan

(C) The Author(s) 2021

Y. Asami et al. (eds.), Frontiers of Real Estate Science in Japan, New Frontiers in

Regional Science: Asian Perspectives 29,

https://doi.org/10.1007/978-981-15-8848-8_7 
system revisions on the bid acceptance ratio, number of bidders, and highest bid using many years of data relating to judicial real estate auctions, including unsuccessful bid data. Furthermore, by comparison and analysis of the abundant data for judicial real estate auctions and voluntary sales as well as general real estate trading (observed numbers were judicial real estate auctions 8268, voluntary sales 6181, and general real estate trading 91,984), this paper clarified that there continues to be a large gap in the selling prices for judicial real estate auctions and general real estate trading even after the series of system revisions, so further system revisions for judicial real estate auctions were also examined.

\subsection{Previous Research}

Previous research on statistical analysis of the judicial real estate auction system includes the following: Taguchi and Ide (2004) calculated the recovery rate and the bid acceptance ratio from judicial real estate auction data in the Osaka District Court to analyze the current state of the auction market and study the role of the minimal sale price. Maruoka (2011) clarified the impact on the highest bid, etc. according to the form of occupancy such as under the suspension of delivery system following the abolition of the short-term tenancy protection system. In addition, Kazumi (2014) clarified the impact of introducing the judicial real estate auction property information site Broadcast Information of Tri-set system (hereinafter, "Broadcast Information of Tri-set system") through a Difference-In-Differences (DID) analysis. Takahashi (2015) analyzed the impact that the revision of the minimal sale price system had on the bid acceptance ratio and highest bid and proposed revisions to the system that prescribes the minimum price basis. Fukui and Kume (2015a), apart from studying the impact that the abolition of the protection of short-term tenancy had on the highest bid, also compared and studied the impact of the short-term tenancy protection on the highest bid before and after the system revision. Reports in international journals include the following: Idee et al. (2011) suggest the state of occupancy for auction real estate affects the highest bid through two paths, namely, the minimal sale price and the change in the number of bidders according to the change in the minimal sale price. In addition, Hoshino and Nakanishi (2016) propose an environment-based economic evaluation method using judicial real estate auction data of the Tokyo District Court.

However, there has been no research to date that has conducted empirical analysis of the series of system revisions over many years using actual judicial real estate auction data, including unsuccessful bids. Furthermore, there has been no research that clarified the extent to which the series of system revision has caused contraction in the divergence between the highest bid for the judicial real estate auctions and the transaction prices for voluntary sales and general real estate trading. So, this paper analyzes the impact of the series of system revisions of judicial real estate auctions, controlling the selection bias by using data that also includes cases of unsuccessful bids, and clarifies the price difference among the highest bid for the judicial real 
estate auctions and prices of voluntary sales and general real estate trading; this paper focuses on further facilitating judicial real estate auctions.

\subsection{Outline of Judicial Real Estate Auctions and Voluntary Sales}

\subsubsection{Outline of Judicial Real Estate Auctions}

Judicial real estate auctions are procedures aimed at recovering a creditor's claim through a compulsory sale by a court of an owner's real estate in accordance with the Civil Execution Act. The court shall, upon a filing by a creditor, seize such real estate, set a certain period as an auction period and sell such real estate to the person with the highest price presented during that time period, with the proceeds of the sale distributed to the creditor(s).

\subsubsection{Outline of Voluntary Sales}

Voluntary sales is a system for the sale of collateral real estate in the general real estate market through a real estate broker based on the intent of the debtor, with proceeds of the sale paid to the creditor(s). Real estate sale procedures are handled by real estate brokers, but creditors are able to control aspects of the selling procedures such as the verification of the appropriateness of the selling price. In the case of voluntary sales, selling takes place in the general real estate market, so the property can be sold at a higher price than would be generated through a judicial real estate auction, and since there are fewer required procedures than for a judicial real estate auction, the period up until the sale is also reportedly shorter. Furthermore, there are benefits for the debtor such as for example where moving costs, etc. are approved as a cost deduction. There are examples where creditors have encouraged debtors to prioritize conducting a voluntary sale over a judicial real estate auction projecting that this would accelerate the sale and increase the claim recovery amount (Ministry of Justice: Auction System Study Group 2007). 


\subsection{Main Revisions of the Judicial Real Estate Auction System}

\subsubsection{Abolition of the Protection of Short-Term Tenancy}

For judicial real estate auction properties, the purchaser through the judicial real estate auction needs to negotiate the eviction with the occupant. The protection of short-term tenancy for such occupants has been thought as the main cause of obstruction for judicial real estate auctions.

A short-term tenancy is, in the case of a lease contract for the building of $<3$ years, the right that enables perfection of the mortgage even if there is a right of lease set at a later date than for the mortgage set during the contract period.

Misuse of this system by setting a short-term tenancy in collusion with debtors and anti-social organizations such as organized crime groups with the modus operandi to require the purchaser to pay a large eviction fee to the occupant following the judicial real estate auction was prevalent (Fukui 2007).

Protection of short-term tenancy increases the risk for financial institutions as lenders and reduces the supply of funds in the financial markets (a shift to the left on the supply curve). On the other hand, the misuse of such system makes obstruction possible increasing the demand in the financial markets (a shift to the right on the demand curve).But the amount of this increase is smaller than the amount of decline in supply. It is difficult for lenders to assess when lending if borrowers are taking a bad faith modus operandi, so the risk increases. This change in the demand and supply in the financial markets causes interest rates to rise and the supply of funds to decline, resulting in a lower surplus. Short-term tenancy was abolished with the 2003 legal revisions.

\subsubsection{Revision of the Minimal Sale Price System}

Traditionally, the minimal sale price was set based on the evaluation of real estate appraisers, and if there are no bids at higher prices, such judicial real estate auction was treated as failed. However, the minimal sale price was changed to a standard sale price in the 2004 revision of the Civil Execution Act, and the auction was finalized if there was a price of at least $80 \%$ of that amount (minimum purchase price).

The auction result will be an unsuccessful bid if the market value pertaining to the auction property is below the minimal sale price. On the other hand, if the market value is higher than the minimum purchase price, the bidding will be effective, leading to a rise in the bid acceptance ratio, thereby making it easier to recover claims with a judicial real estate auction. 


\subsubsection{Introduction of Information Provided Through the Internet}

The details of properties to be auctioned had traditionally been made public by leaving it to the individual court conducting the auction. But now the provision of information via the internet using the Broadcast Information of Tri-set system ${ }^{1}$ has expanded by the 2003 revisions to the Civil Execution Act.

With the introduction of the Broadcast Information of Tri-set system, the cost to auction participants to obtain property information was reduced, and the expectations that buyers who had previously found it difficult to acquire information will be more incentivized to participate will increase the demand for judicial real estate auctions (a shift to the right on the demand curve). Consequently, this will lead to an increase in the highest bids and an increase in the number of bidders for judicial real estate auctions.

\subsection{Empirical Analysis of the Impact of System Revisions of Judicial Real Estate Auctions}

\subsubsection{Hypothesis to be Verified}

Based on the hypothesis that the revision of the judicial real estate auction system, reported in Sect. 7.4, contributed to facilitation of judicial real estate auctions bringing about increases of bid acceptance ratio, the increases of the number of bidders as well as of the highest bids for each auction, this paper verified such hypothesis by using data for actual judicial real estate auctions.

\subsubsection{Data}

This paper uses individual data of actual judicial real estate auctions to build a database combining them, on an auction-by-auction basis, with information on property attributes and sales results obtained from Career-Design Limited, and information mentioned in "Property Specifications", "Report on Survey of Current Status", and "Evaluation Report" obtained from Estate Times Co., Ltd. Note that from the perspective of constraints on data, the data used in this paper refer to auctions undertaken by the central office and each branch office of the Tokyo District Court, Chiba District Court, Yokohama District Court, and the Saitama District Court. For these areas, the analysis was limited to residential condominiums for

${ }^{1}$ http://bit.sikkou.jp/app/top/pt001/h01/ 
Table 7.1 Periods for system revisions of judicial real estate auctions

\begin{tabular}{l|l}
\hline FY & Outline of the system revision \\
\hline 2002 & $\begin{array}{l}\text { The Broadcast Information of Tri-set system was introduced at the central office of the } \\
\text { Tokyo District Court }\end{array}$ \\
\hline 2004 & Abolition of the protection of short-term tenancy \\
\hline 2005 & Revision of the minimal sale price system \\
\hline 2006 & $\begin{array}{l}\text { The Broadcast Information of Tri-set system was introduced at the Tachikawa branch of } \\
\text { Tokyo District Court Yokohama District Court (central office and Odawara branch), and } \\
\text { whole area of District Court in Chiba and Saitama }\end{array}$ \\
\hline 2008 & $\begin{array}{l}\text { The Broadcast Information of Tri-set system was introduced at Yokohama District Court } \\
\text { (Kawasaki branch, Yokosuka branch, Sagamihara branch). The Broadcast Information of } \\
\text { Tri-set system was introduced at all of the District Court in one metropolitan and three } \\
\text { prefectures }\end{array}$ \\
\hline
\end{tabular}

which biddings were held in fiscal years FY2001, FY2003, FY2004, FY2005, and FY2009 that were around the times when revisions to the auction system were implemented (the system revision periods are set out in Table 7.1). Note that the dataset was restricted to residential condominiums because the properties indicate a single price for land and buildings and are generally standardized, which made it easier for analysis focused on system revisions.

\subsubsection{Estimation Model}

Analysis was conducted using the following model. The system revision dummy was indicated by a dummy variable of 1 following revision and 0 before revision. To confirm the effect of the system revision, attention was paid to the result of this variable in each of model (a), model (b), and model (c).

$\alpha$ is a constant term, and $\varepsilon$ is an error term. $\mathrm{Z}$ is vector and includes control variables that impact on the bid acceptance ratio such as the distance from the nearest station. Note that the control variables ${ }^{2}$ are set out in Table 7.2, and the basic statistics are set out in Table 7.3.

(a) $\operatorname{Pr}$ (successful bid dummy $=1)=\mathrm{G}\left(\alpha+\beta\right.$ system revision dummy $\left.+\delta^{\prime} \mathrm{Z}\right)$

(b) $N$ (number of bidders) $=\alpha+\beta$ system revision dummy $+\delta^{\prime} \mathrm{Z}+\varepsilon$

(c) $\operatorname{lnP}$ (highest bid) $=\alpha+\beta$ system revision dummy $+\delta^{\prime} Z+\varepsilon$

Model (a) is a Probit model to analyze the impact that system revisions have on the bid acceptance ratio, and function $\mathrm{G}$ indicates the distribution function of the standard

\footnotetext{
${ }^{2}$ As for variables that control the macro factors in the real estate market, the fiscal year dummy has multicollinearity since system revisions were conducted in terms of fiscal years. So, adopted the cross terms between the distance to the nearest station, which is one property attribute that has a certain impact on the highest bid and bid acceptance ratio, etc. without being impacted by the fiscal year, and the fiscal year dummy as the independent variable.
} 
Table 7.2 Control variables used

\begin{tabular}{|c|c|}
\hline Variables & Definition \\
\hline Distance from the nearest station & Road distance from the nearest station $(\mathrm{km})$ \\
\hline District Court dummy(Tokyo) & $\begin{array}{l}\text { Dummy variable to indicate judicial real estate auctions } \\
\text { by District Court (construction site is Tokyo Metropolitan } \\
\text { Area) is } 1\end{array}$ \\
\hline District Court dummy (Saitama) & $\begin{array}{l}\text { Dummy variable to indicate judicial real estate auctions } \\
\text { by District Court (construction site is Saitama prefecture) } \\
\text { is } 1\end{array}$ \\
\hline District Court dummy (Chiba) & $\begin{array}{l}\text { Dummy variable to indicate judicial real estate auctions } \\
\text { by District Court (construction site is Chiba prefecture) is } \\
1\end{array}$ \\
\hline Exclusive area & Floor space of exclusive elements $\left(\mathrm{m}^{2}\right)$ \\
\hline Balcony dummy & Dummy variable to have a balcony is 1 \\
\hline Total number of households & Total number of households with the condominium \\
\hline Number of floors & Floor number where exclusive elements are located \\
\hline Total number of floors & Total number of floors with the condominium \\
\hline Number of years from construction & $\begin{array}{l}\text { The number of years from construction date to bid open- } \\
\text { ing date }\end{array}$ \\
\hline $\begin{array}{l}\text { SRC (steel framed reinforced con- } \\
\text { crete) structure dummy }\end{array}$ & $\begin{array}{l}\text { Dummy variable to indicate the condominium which is } \\
\text { SRC structure is } 1\end{array}$ \\
\hline Arrears of maintenance fee dummy & $\begin{array}{l}\text { Dummy variable to indicate where there is arrears of } \\
\text { maintenance fee is } 1\end{array}$ \\
\hline Short-term tenancy dummy & Dummy variable to set short-term tenancy is 1 \\
\hline Lease dummy & Dummy variable to set right of lease is 1 \\
\hline Third-party occupation dummy & Dummy variable to occupy by the third party is 1 \\
\hline $\begin{array}{l}\text { Minimal sale price (minimum pur- } \\
\text { chase price after FY2005) }\end{array}$ & $\begin{array}{l}\text { Minimal sale price (minimum purchase price after } \\
\text { FY2005) (10,000 yen) }\end{array}$ \\
\hline
\end{tabular}

normal distribution. The dependent variable is the successful bid dummy, and the dummy variable to indicate transactions with a successful bid is 1 , while cases of unsuccessful bids are indicated by 0 . Analysis was conducted using this model.

Model (b) is a linear regression model to analyze the impact that system revisions have on the number of bidders, and makes estimates using the Ordinary Least Squares (OLS) with the number of bidders as dependent variable.

Model (c) is a linear regression model to analyze the impact that system revisions have on the highest bid. For judicial real estate auctions, since there is a selection bias caused by analysis being limited to data relating to successful bids with data for the highest bid on transactions with unsuccessful bids being dismissed, the estimated amount by OLS lacks consistency. So in this paper, analysis was conducted using the following method.

\section{Heckit Model}

This model is a two-stage estimation model that takes a variable that is observable when a latent variable satisfies certain conditions yet unobservable when the 
Table 7.3 Basic statistics

\begin{tabular}{|c|c|c|c|c|c|}
\hline Variables & $\begin{array}{l}\text { Number of } \\
\text { observation }\end{array}$ & Average & $\begin{array}{l}\text { Standard } \\
\text { deviation }\end{array}$ & $\begin{array}{l}\text { Minimum } \\
\text { value }\end{array}$ & $\begin{array}{l}\text { Maximum } \\
\text { value }\end{array}$ \\
\hline Successful bid dummy & 17,684 & 0.896290 & 0.304892 & 0 & 1 \\
\hline Number of bidders & 17,684 & 8.294108 & 8.387802 & 0 & 87 \\
\hline $\begin{array}{l}\text { ln Highest bid (ln is nat- } \\
\text { ural logarithm) }\end{array}$ & 15,850 & 16.101440 & 0.738086 & 12.72784 & 25.01517 \\
\hline $\begin{array}{l}\text { Introduction of Broadcast } \\
\text { Information of Tri-set } \\
\text { system dummy }\end{array}$ & 17,684 & 0.453687 & 0.497865 & 0 & 1 \\
\hline $\begin{array}{l}\text { Abolition of the protec- } \\
\text { tion of short-term tenancy } \\
\text { dummy }\end{array}$ & 17,684 & 0.623332 & 0.484564 & 0 & 1 \\
\hline $\begin{array}{l}\text { Revision of minimal sale } \\
\text { price system dummy }\end{array}$ & 17,684 & 0.440851 & 0.496503 & 0 & 1 \\
\hline $\begin{array}{l}\text { Distance from the nearest } \\
\text { station }\end{array}$ & 17,684 & 1.226735 & 1.476636 & 0.03 & 18.64 \\
\hline $\begin{array}{l}\text { FY } 2003 \text { dummy } * \text { Dis- } \\
\text { tance from the nearest } \\
\text { station }\end{array}$ & 17,684 & 0.242780 & 0.847284 & 0 & 15.36 \\
\hline $\begin{array}{l}\text { FY } 2004 \text { dummy * Dis- } \\
\text { tance from the nearest } \\
\text { station }\end{array}$ & 17,684 & 0.231452 & 0.834275 & 0 & 16.24 \\
\hline $\begin{array}{l}\text { FY } 2005 \text { dummy } * \text { Dis- } \\
\text { tance from the nearest } \\
\text { station }\end{array}$ & 17,684 & 0.231587 & 0.834928 & 0 & 18.64 \\
\hline $\begin{array}{l}\text { FY } 2009 \text { dummy } * \text { Dis- } \\
\text { tance from the nearest } \\
\text { station }\end{array}$ & 17,684 & 0.276397 & 0.692386 & 0 & 13.5 \\
\hline $\begin{array}{l}\text { District Court dummy } \\
\text { (Tokyo) }\end{array}$ & 17,684 & 0.421398 & 0.493797 & 0 & 1 \\
\hline $\begin{array}{l}\text { District Court dummy } \\
\text { (Saitama) }\end{array}$ & 17,684 & 0.119996 & 0.324965 & 0 & 1 \\
\hline $\begin{array}{l}\text { District Court dummy } \\
\text { (Chiba) }\end{array}$ & 17,684 & 0.159749 & 0.366383 & 0 & 1 \\
\hline Exclusive area & 17,684 & 58.279340 & 102.012800 & 5.47 & 7524 \\
\hline Balcony dummy & 17,684 & 0.968220 & 0.175419 & 0 & 1 \\
\hline $\begin{array}{l}\text { Total number of } \\
\text { households }\end{array}$ & 17,684 & 78.179430 & 111.820200 & 2 & 2233 \\
\hline Number of floors & 17,684 & 4.206537 & 2.990483 & 1 & 52 \\
\hline Total number of floors & 17,684 & 7.570233 & 3.777935 & 1 & 56 \\
\hline $\begin{array}{l}\text { Number of years from } \\
\text { construction }\end{array}$ & 17,684 & 17.686100 & 9.450777 & 0.7150685 & 110.2658 \\
\hline $\begin{array}{l}\text { SRC (steel framed } \\
\text { reinforced concrete) } \\
\text { structure dummy }\end{array}$ & 17,684 & 0.285060 & 0.451456 & 0 & 1 \\
\hline $\begin{array}{l}\text { Arrears of maintenance } \\
\text { fee dummy }\end{array}$ & 17,684 & 0.759387 & 0.427468 & 0 & 1 \\
\hline
\end{tabular}


Table 7.3 (continued)

\begin{tabular}{l|l|l|l|l|l}
\hline Variables & $\begin{array}{l}\text { Number of } \\
\text { observation }\end{array}$ & Average & $\begin{array}{l}\text { Standard } \\
\text { deviation }\end{array}$ & $\begin{array}{l}\text { Minimum } \\
\text { value }\end{array}$ & $\begin{array}{l}\text { Maximum } \\
\text { value }\end{array}$ \\
\hline $\begin{array}{l}\text { Short-term tenancy } \\
\text { dummy }\end{array}$ & 17,684 & 0.093474 & 0.291104 & 0 & 1 \\
\hline Lease dummy & 17,684 & 0.029405 & 0.168944 & 0 & 1 \\
\hline $\begin{array}{l}\text { Third-party occupation } \\
\text { dummy }\end{array}$ & 17,684 & 0.048575 & 0.214984 & 0 & 1 \\
\hline $\begin{array}{l}\text { Minimal sale price (mini- } \\
\text { mum purchase price after } \\
\text { FY2005) }\end{array}$ & 17,684 & 791.467000 & 885.089000 & 0.8 & 31,879 \\
\hline
\end{tabular}

condition is not met to be a dependent variable, then conducts an OLS estimate calculating the mills ratio for each sample from the maximum-likelihood estimation results for the Probit model of the auctions with successful bid and unsuccessful bid, adding the estimated inverse number of mills ratio (inverse mills ratio) to the independent variables ${ }^{3}$ (Yamamoto 2015).

\section{Switching Regression Model}

This is the model ${ }^{4}$ adopted by Fukui and Kume (2015b). The first stage is a Probit analysis of auctions with successful bids and unsuccessful bids that estimates the prior bid acceptance ratio for each property based on these results, with an estimate in the second stage by adding this to the independent variables in OLS.

\subsubsection{Estimation Results and Consideration}

\section{Bid Acceptance Ratio}

The estimation results in model (a) are presented in Table 7.4. The bid acceptance ratio was at $1 \%$ levels with the introduction of the Broadcast Information of Tri-set system and the abolition of the protection of short-term tenancy, and 5\% levels with the minimum sales price system revision. Both results were respectively statistically significant increases. The removal of the burden to evict occupants and the ease of acquiring property information are thought to have increased the bid acceptance ratio. In addition, the effect of the revision to the minimal sale price system led to a

\footnotetext{
${ }^{3}$ Since the estimate of the parameter dependent on the nonlinearity of the mills ratio is unstable, in practice, it is desirable to add variables that are only included in the first stage. Therefore, the Probit analysis conducted in first stage made its estimates by adding the minimal sale price to the independent variables in the OLS analysis in the second stage.

${ }^{4}$ Adopted also by Fukui and Kume (2015a) and Taguchi and Ide (2004).
} 
Table 7.4 Estimation results (bid acceptance ratio)

\begin{tabular}{l|l|l|l}
\hline & \multicolumn{3}{l}{ Successful bid dummy } \\
\cline { 2 - 4 } & Coefficient & & $\begin{array}{l}\text { Standard } \\
\text { error }\end{array}$ \\
\hline $\begin{array}{l}\text { Introduction of Broadcast Information of Tri-set system } \\
\text { dummy }\end{array}$ & 0.029255 & $* * *$ & 0.006196 \\
\hline Abolition of the protection of short-term tenancy dummy & 0.066619 & $* * *$ & 0.008647 \\
\hline Revision of minimal sale price system dummy & 0.018516 & $* *$ & 0.008258 \\
\hline Distance from the nearest station & -0.018095 & $* * *$ & 0.001915 \\
\hline FY 2003 dummy * Distance from the nearest station & 0.005268 & $* *$ & 0.002351 \\
\hline FY 2004 dummy * Distance from the nearest station & 0.004448 & & 0.003130 \\
\hline FY 2005 dummy * Distance from the nearest station & 0.007213 & $* *$ & 0.003079 \\
\hline FY 2009 dummy * Distance from the nearest station & -0.014541 & $* * *$ & 0.003524 \\
\hline District Court dummy(Tokyo) & -0.015163 & $* * *$ & 0.005761 \\
\hline District Court dummy(Saitama) & -0.037347 & $* * *$ & 0.008235 \\
\hline District Court dummy(Chiba) & 0.016751 & $* * *$ & 0.005795 \\
\hline Exclusive area & -0.000031 & $* *$ & 0.000014 \\
\hline Balcony dummy & 0.056560 & $* * *$ & 0.014043 \\
\hline Total number of households & 0.000058 & $* * *$ & 0.000022 \\
\hline Number of floors & 0.000130 & & 0.000986 \\
\hline Total number of floors & 0.008565 & $* * *$ & 0.001003 \\
\hline Number of years from construction & -0.003219 & $* * *$ & 0.000212 \\
\hline SRC (steel framed reinforced concrete) structure dummy & 0.017912 & $* * *$ & 0.006127 \\
\hline Arrears of maintenance fee dummy & -0.003490 & & 0.004596 \\
\hline Short-term tenancy dummy & 0.020653 & $* * *$ & 0.005972 \\
\hline Lease dummy & 0.013345 & & 0.010503 \\
\hline Third-party occupation dummy & -0.056804 & $* * *$ & 0.014436 \\
\hline Minimal sale price (minimum purchase price after FY2005) & -0.000007 & $* * *$ & 0.000002 \\
\hline Pseudo R-squared (McFadden) & 0.1162 & & \\
\hline Number of observation & 17,684 & & \\
\hline & & & \\
\hline
\end{tabular}

***, **, * means statistically significant at the $1 \%$ level, $5 \%$ level, and $10 \%$ level, respectively

decline in the border amount, which was effective for bidding and is thought to have facilitated successful bidding. If an auction result is an unsuccessful bid, it takes time and effort for the creditor due to the requirement for another auction, etc. Given that many auction practitioners are dissatisfied with the selling period and selling ratio (Cabinet Office 2007), the system revisions appear to have had a certain impact.

\section{Number of Bidders}

The estimation results for model (b) are presented in Table 7.5. The number of bidders increased at a statistically significant level of $1 \%$ levels for each bidding, with the introduction of the Broadcast Information of Tri-set system and abolition of 
Table 7.5 Estimation results (number of bidders)

\begin{tabular}{|c|c|c|c|}
\hline & \multicolumn{3}{|c|}{ Number of bidders } \\
\hline & Coefficient & & $\begin{array}{l}\text { Standard } \\
\text { error }\end{array}$ \\
\hline $\begin{array}{l}\text { Introduction of Broadcast Information of Tri-set system } \\
\text { dummy }\end{array}$ & 1.903679 & $* * *$ & 0.177896 \\
\hline Abolition of the protection of short-term tenancy dummy & 2.379518 & $* * *$ & 0.210086 \\
\hline Revision of minimal sale price system dummy & 0.030601 & & 0.219975 \\
\hline Distance from the nearest station & -0.870920 & $* * *$ & 0.071568 \\
\hline FY 2003 dummy * Distance from the nearest station & 0.212098 & $* *$ & 0.089188 \\
\hline FY 2004 dummy $*$ Distance from the nearest station & -0.092948 & & 0.109304 \\
\hline FY 2005 dummy $*$ Distance from the nearest station & -0.095886 & & 0.104140 \\
\hline FY 2009 dummy * Distance from the nearest station & -0.394543 & $* * *$ & 0.123737 \\
\hline District Court dummy (Tokyo) & -0.618697 & $* * *$ & 0.162440 \\
\hline District Court dummy (Saitama) & -1.585154 & $* * *$ & 0.196756 \\
\hline District Court dummy (Chiba) & -0.931440 & $* * *$ & 0.179811 \\
\hline Exclusive area & -0.001564 & $* * *$ & 0.000579 \\
\hline Balcony dummy & 1.879682 & $* * *$ & 0.326402 \\
\hline Total number of households & 0.002243 & $* * *$ & 0.000569 \\
\hline Number of floors & 0.265480 & $* * *$ & 0.024215 \\
\hline Total number of floors & 0.322022 & $* * *$ & 0.023669 \\
\hline Number of years from construction & -0.181952 & $* * *$ & 0.006458 \\
\hline SRC (steel framed reinforced concrete) structure dummy & 0.797125 & $* * *$ & 0.160113 \\
\hline Arrears of maintenance fee dummy & -0.089958 & & 0.134943 \\
\hline Short-term tenancy dummy & 0.728060 & $* * *$ & 0.198212 \\
\hline Lease dummy & -0.788224 & $* *$ & 0.337954 \\
\hline Third-party occupation dummy & -1.123583 & $* * *$ & 0.278299 \\
\hline Minimal sale price (minimum purchase price after FY2005) & -0.000060 & & 0.000071 \\
\hline Constant term & 5.360559 & $* * *$ & 0.412418 \\
\hline Adjusted R-squared & 0.1955 & & \\
\hline Number of observation & 17,684 & & \\
\hline
\end{tabular}

the protection of short-term tenancy, leading to respective increases of about 1.9 cases and about 2.4 cases.

\section{Highest Bid}

The estimation results concerning the highest bid are presented in Table 7.6. Note that the estimate used a robust estimator that accounted for the heteroskedasticity of the disturbance term.

In the Heckit Model, the dummy coefficients for the introduction of the Broadcast Information of Tri-set system, the abolition of the protection of short-term tenancy, and the revision of the minimal sale price system were respectively about 0.281 , 
Table 7.6 Estimation results (highest bid)

\begin{tabular}{|c|c|c|c|c|c|c|}
\hline \multirow[t]{2}{*}{$\begin{array}{l}\text { ln Highest bid (ln is natural } \\
\text { logarithm) }\end{array}$} & \multicolumn{3}{|c|}{ (1) Heckit Model } & \multicolumn{3}{|c|}{$\begin{array}{l}\text { (2) Switching Regression } \\
\text { Model }\end{array}$} \\
\hline & Coefficient & & $\begin{array}{l}\text { Standard } \\
\text { error }\end{array}$ & Coefficient & & $\begin{array}{l}\text { Standard } \\
\text { error }\end{array}$ \\
\hline $\begin{array}{l}\text { Introduction of Broadcast } \\
\text { Information of Tri-set system } \\
\text { dummy }\end{array}$ & 0.280951 & $* * *$ & 0.017291 & 0.273028 & $* * *$ & 0.016854 \\
\hline $\begin{array}{l}\text { Abolition of the protection of } \\
\text { short-term tenancy dummy }\end{array}$ & 0.225432 & $* * *$ & 0.024186 & 0.203378 & $* * *$ & 0.023046 \\
\hline $\begin{array}{l}\text { Revision of minimal sale price } \\
\text { system dummy }\end{array}$ & 0.053545 & $* * *$ & 0.018827 & 0.044444 & $* *$ & 0.018747 \\
\hline $\begin{array}{l}\text { Distance from the nearest } \\
\text { station }\end{array}$ & -0.154464 & $* * *$ & 0.012305 & -0.150825 & $* * *$ & 0.012183 \\
\hline $\begin{array}{l}\text { FY } 2003 \text { dummy } * \text { Distance } \\
\text { from the nearest station }\end{array}$ & 0.035478 & $* * *$ & 0.010020 & 0.033011 & $* * *$ & 0.009794 \\
\hline $\begin{array}{l}\text { FY } 2004 \text { dummy } * \text { Distance } \\
\text { from the nearest station }\end{array}$ & 0.044638 & $* * *$ & 0.012183 & 0.045043 & $* * *$ & 0.012152 \\
\hline $\begin{array}{l}\text { FY } 2005 \text { dummy } * \text { Distance } \\
\text { from the nearest station }\end{array}$ & 0.079950 & $* * *$ & 0.012102 & 0.080091 & $* * *$ & 0.012134 \\
\hline $\begin{array}{l}\text { FY } 2009 \text { dummy } * \text { Distance } \\
\text { from the nearest station }\end{array}$ & -0.115506 & $* * *$ & 0.013930 & -0.106195 & $* * *$ & 0.013883 \\
\hline District Court dummy (Tokyo) & 0.171422 & $* * *$ & 0.014986 & 0.179578 & $* * *$ & 0.015058 \\
\hline $\begin{array}{l}\text { District Court dummy } \\
\text { (Saitama) }\end{array}$ & -0.262486 & $* * *$ & 0.016934 & -0.249919 & $* * *$ & 0.016826 \\
\hline District Court dummy (Chiba) & -0.081872 & $* * *$ & 0.018503 & -0.086844 & $* * *$ & 0.018360 \\
\hline Exclusive area & 0.001098 & & 0.000696 & 0.001099 & & 0.000693 \\
\hline Balcony dummy & 0.353136 & $* * *$ & 0.039745 & 0.340767 & $* * *$ & 0.039754 \\
\hline Total number of households & 0.000216 & $* * *$ & 0.000052 & 0.000238 & $* * *$ & 0.000055 \\
\hline Number of floors & 0.014581 & $* * *$ & 0.002027 & 0.017180 & $* * *$ & 0.002591 \\
\hline Total number of floors & 0.055332 & $* * *$ & 0.003117 & 0.047514 & $* * *$ & 0.004448 \\
\hline $\begin{array}{l}\text { Number of years from } \\
\text { construction }\end{array}$ & -0.038153 & $* * *$ & 0.001183 & -0.037250 & $* * *$ & 0.001103 \\
\hline $\begin{array}{l}\text { SRC (steel framed reinforced } \\
\text { concrete) structure dummy }\end{array}$ & 0.035914 & $* *$ & 0.015778 & 0.042056 & $* *$ & 0.017420 \\
\hline $\begin{array}{l}\text { Arrears of maintenance fee } \\
\text { dummy }\end{array}$ & -0.119407 & $* * *$ & 0.012299 & -0.116638 & $* * *$ & 0.012275 \\
\hline Short-term tenancy dummy & -0.208982 & $* * *$ & 0.019375 & -0.216997 & $* * *$ & 0.019310 \\
\hline Lease dummy & -0.115840 & $* * *$ & 0.033100 & -0.117928 & $* * *$ & 0.033134 \\
\hline $\begin{array}{l}\text { Third-party occupation } \\
\text { dummy }\end{array}$ & -0.232199 & $* * *$ & 0.028446 & -0.213770 & $* * *$ & 0.027922 \\
\hline Inverse mills ratio & 2.070307 & $* * *$ & 0.169656 & & & \\
\hline Bid acceptance ratio $^{a}$ & & & & -3.104957 & $* * *$ & 0.261791 \\
\hline
\end{tabular}


Table 7.6 (continued)

\begin{tabular}{|c|c|c|c|c|c|c|}
\hline \multirow[t]{2}{*}{$\begin{array}{l}\text { ln Highest bid (ln is natural } \\
\text { logarithm) }\end{array}$} & \multicolumn{3}{|c|}{ (1) Heckit Model } & \multicolumn{3}{|c|}{$\begin{array}{l}\text { (2) Switching Regression } \\
\text { Model }\end{array}$} \\
\hline & Coefficient & & $\begin{array}{l}\text { Standard } \\
\text { error }\end{array}$ & Coefficient & & $\begin{array}{l}\text { Standard } \\
\text { error }\end{array}$ \\
\hline Constant term & 15.434850 & $* * *$ & 0.064930 & 18.667600 & $* * *$ & 0.235925 \\
\hline Adjusted R-squared & 0.3343 & & & 0.3334 & & \\
\hline Number of observation & 15,850 & & & 15,850 & & \\
\hline
\end{tabular}

$* * *, * *, *$ means statistically significant at the $1 \%$ level, $5 \%$ level, and $10 \%$ level, respectively

${ }^{a}$ The coefficient for the bid acceptance, which is the independent variables in the switching regression model, is negative. There are three main causes for the high bid acceptance ratio: (1) minimal sale price is low, (2) there are many bidders, and (3) the high bids of bidders. Of these, as the bid acceptance ratio increases, the highest bid also rises for (2) and (3), but in the case that (1) the minimal sale price is low, the bid acceptance ratio increases but the highest bid falls. The estimation results suggest that the cause (1) changes the bid acceptance ratio more than causes (2) and (3). Therefore, the higher the bid acceptance ratio for a property, the lower the highest bid.

0.225 , and 0.054 , which were all statistically significant at the $1 \%$ level for respectively increasing the successful bid price by about $32.4 \%, 25.3 \%$, and $5.5 \%$.

While there is a difference in the coefficient and significance level under the Switching Regression Model compared to the results from the Heckit Model, the order of impact from the system revision had a similar result.

\subsection{Empirical Analysis Concerning the Price Difference for Judicial Real Estate Auctions, Voluntary Sales, and General Real Estate Trading Prices}

\subsubsection{Background to the Problem and the Hypothesis to be Verified}

As described in Sect. 7.5.4.3, the system revision was confirmed to have a positive effect on the highest bid for judicial real estate auctions, and the price difference between judicial real estate auctions, voluntary sales, and general real estate trading is verified based on the hypothesis that "even following the series of system revisions, the price was kept lower than the price of voluntary sales and general real estate trades".

\subsubsection{Data}

We use the individual data for properties that were sold through judicial real estate auctions, voluntary sales, and general real estate trading from 2012 to 2014 in the Tokyo Metropolitan Area, Chiba Prefecture, Kanagawa Prefecture, and Saitama 
Table 7.7 Control variables used

\begin{tabular}{l|l}
\hline Variables & Definition \\
\hline Tokyo dummy & $\begin{array}{l}\text { Dummy variable to sell in Tokyo Metropolitan Area } \\
\text { is } 1\end{array}$ \\
\hline Saitama dummy & Dummy variable to sell in Saitama prefecture is 1 \\
\hline Chiba dummy & Dummy variable to sell in Chiba prefecture is 1 \\
\hline CY2013 dummy & Dummy variable to sell in 2013 is 1 \\
\hline CY2014 dummy & Dummy variable to sell in 2014 is 1 \\
\hline Distance from the nearest station & Road distance from the nearest station (km) \\
\hline Exclusive area & Floor space of exclusive elements (m $\left.{ }^{2}\right)$ \\
\hline $\begin{array}{l}\text { SRC (steel framed reinforced concrete) } \\
\text { structure dummy }\end{array}$ & $\begin{array}{l}\text { Dummy variable to indicate the condominium which } \\
\text { is SRC structure is } 1\end{array}$ \\
\hline Total number of floors & Total number of floors with the condominium \\
\hline Number of floors & Floor number where exclusive elements is located \\
\hline Number of years from construction & $\begin{array}{l}\text { The number of years from construction date to bid } \\
\text { opening date }\end{array}$ \\
\hline Balcony dummy & Dummy variable to have a balcony is 1 \\
\hline Possessor occupation dummy & Dummy variable to occupy by possessor is 1 \\
\hline Short-term tenancy dummy & Dummy variable to set short-term tenancy is 1 \\
\hline Lease dummy & Dummy variable to set right of lease is 1 \\
\hline Third-party occupation dummy & Dummy variable to occupy by the third party is 1 \\
\hline &
\end{tabular}

Prefecture (one metropolitan area and three prefectures). The database was built using the same method as for judicial real estate auctions referred to in Sect. 7.5.2., and data for general real estate trading were obtained from the Real Estate Information Network for East Japan. For voluntary sales, transactions for voluntary sales were identified based on the data acquired from the Japan Housing Finance Agency and matched with the data for general real estate trading. Note that as with Sect. 7.5.2, the property types were limited to residential condominiums to verify the effect focusing on the method of procedures. Note that the control variables are as shown in Table 7.7, and the basic statistics are as shown in Table 7.8.

\subsubsection{Estimation Model}

A linear regression model is used with estimation through OLS to grasp the difference in the selling price that focuses on property disposal methods for model (d), secular change for model (e), and the state of property occupancy for judicial real estate auctions for model (f). $\alpha$ is a constant term, $\varepsilon$ indicates an error term, and ? is vector and includes control variables for the impact on the selling price such as the distance from the nearest station.

(d) $\ln \mathrm{P}$ (selling price) $=\alpha+\beta$ auction dummy $+\gamma$ voluntary sale dummy $+\delta^{\prime}$ ? $+\varepsilon$

(e) $\ln \mathrm{P}$ (selling price) $=\alpha+\beta$ auction dummy $*$ annual dummy $+\delta^{\prime}$ ? $+\varepsilon$

(f) $\ln \mathrm{P}$ (selling price) $=\alpha+\beta$ auction dummy $*$ occupancy state dummy $+\delta^{\prime} ?+\varepsilon$ 
Table 7.8 Basic statistics

\begin{tabular}{|c|c|c|c|c|c|}
\hline Variables & $\begin{array}{l}\text { Number of } \\
\text { observations }\end{array}$ & Average & $\begin{array}{l}\text { Standard } \\
\text { deviation }\end{array}$ & $\begin{array}{l}\text { Minimum } \\
\text { value }\end{array}$ & $\begin{array}{l}\text { Maximum } \\
\text { value }\end{array}$ \\
\hline $\begin{array}{l}\text { In selling price (ln is natu- } \\
\text { ral logarithm) }\end{array}$ & 106,433 & 16.790300 & 0.769939 & 9.729134 & 19.70161 \\
\hline Auction dummy & 106,433 & 0.077683 & 0.267673 & 0 & 1 \\
\hline Voluntary sale dummy & 106,433 & 0.058074 & 0.233885 & 0 & 1 \\
\hline Tokyo dummy & 106,433 & 0.483422 & 0.499727 & 0 & 1 \\
\hline Saitama dummy & 106,433 & 0.125581 & 0.331379 & 0 & 1 \\
\hline Chiba dummy & 106,433 & 0.132534 & 0.339072 & 0 & 1 \\
\hline CY2013 dummy & 106,433 & 0.358113 & 0.479448 & 0 & 1 \\
\hline CY2014 dummy & 106,433 & 0.326337 & 0.468874 & 0 & 1 \\
\hline $\begin{array}{l}\text { Auction dummy * CY2012 } \\
\text { dummy }\end{array}$ & 106,433 & 0.028318 & 0.165881 & 0 & 1 \\
\hline $\begin{array}{l}\text { Auction dummy * CY2013 } \\
\text { dummy }\end{array}$ & 106,433 & 0.028196 & 0.165534 & 0 & 1 \\
\hline $\begin{array}{l}\text { Auction dummy * CY2014 } \\
\text { dummy }\end{array}$ & 106,433 & 0.021168 & 0.143946 & 0 & 1 \\
\hline $\begin{array}{l}\text { Auction dummy } * \text { possessor } \\
\text { occupation dummy }\end{array}$ & 106,433 & 0.057125 & 0.232083 & 0 & 1 \\
\hline $\begin{array}{l}\text { Auction dummy } * \text { short- } \\
\text { term tenancy dummy }\end{array}$ & 106,433 & 0.000996 & 0.031543 & 0 & 1 \\
\hline $\begin{array}{l}\text { Auction dummy * lease } \\
\text { dummy }\end{array}$ & 106,433 & 0.001259 & 0.035460 & 0 & 1 \\
\hline $\begin{array}{l}\text { Auction dummy * third- } \\
\text { party occupation dummy }\end{array}$ & 106,433 & 0.018331 & 0.134145 & 0 & 1 \\
\hline $\begin{array}{l}\text { Distance from the nearest } \\
\text { station }\end{array}$ & 106,433 & 0.989974 & 1.207653 & 0.007 & 18.4 \\
\hline Exclusive area & 106,433 & 64.231160 & 21.570810 & 8.75 & 492.58 \\
\hline $\begin{array}{l}\text { SRC (steel framed } \\
\text { reinforced concrete) struc- } \\
\text { ture dummy }\end{array}$ & 106,433 & 0.259910 & 0.438587 & 0 & 1 \\
\hline Total number of floors & 106,433 & 10.082150 & 7.319233 & 1 & 61 \\
\hline Number of floors & 106,433 & 5.549858 & 5.061002 & 1 & 58 \\
\hline $\begin{array}{l}\text { Number of years from } \\
\text { construction }\end{array}$ & 106,433 & 19.213800 & 11.731000 & 0.1150685 & 114.7562 \\
\hline Balcony dummy & 106,433 & 0.925437 & 0.262687 & 0 & 1 \\
\hline
\end{tabular}

\subsubsection{Estimation Results}

The estimation results from models (d) to (f) are presented in Table 7.9. Compared to general real estate trading, the selling price is lower at a $1 \%$ level of statistical significance of about $3.8 \%$ for voluntary sales and about $37.7 \%$ for judicial real estate auctions. In addition, although the price difference between general real estate trading and auctions contracted from 2012 to 2014, the price difference remains large. Note that there was no large difference evident according to differences in the state of occupancy. 


\begin{tabular}{|c|c|c|c|c|c|c|c|c|c|c|c|c|c|c|c|c|c|c|c|c|c|c|}
\hline 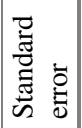 & & & & & & 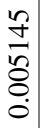 & 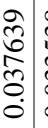 & 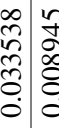 & 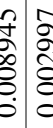 & 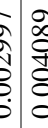 & \begin{tabular}{l}
$\hat{8}$ \\
\multirow{8}{*}{} \\
8 \\
0
\end{tabular} & 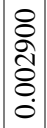 & 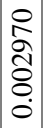 & 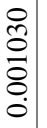 & 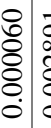 & 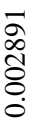 & 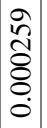 & $\begin{array}{l}\tilde{t} \\
\tilde{8} \\
\delta \\
\vdots \\
0\end{array}$ & $\begin{array}{l}0 \\
\bar{\Xi} \\
8 \\
8 \\
0 \\
0\end{array}$ & 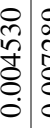 & & \\
\hline & & & & & & $\begin{array}{l}* \\
* \\
*\end{array}$ & 芩 & \begin{tabular}{r|r}
$*$ & $*$ \\
$*$ & $*$ \\
$*$
\end{tabular} & 觪 & $\frac{*}{*}$ & 草 & $\begin{array}{l}* \\
\stackrel{*}{*} \\
*\end{array}$ & 粒 & 蒾 & 烣 & 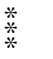 & 宷 & 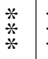 & * & * & & \\
\hline 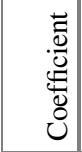 & & & & & & 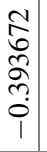 & $\begin{array}{l}0 \\
\hat{2} \\
n \\
0 \\
\vdots \\
\vdots \\
0 \\
1\end{array}$ & 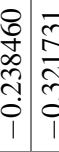 & 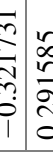 & 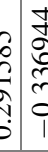 & 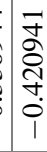 & $\begin{array}{c}2 \\
\mathcal{Y} \\
\tilde{n} \\
\tilde{0} \\
0 \\
0\end{array}$ & $\begin{array}{l}\hat{\sigma} \\
\tilde{N} \\
\tilde{2} \\
0 \\
0\end{array}$ & $\begin{array}{l}a \\
\vec{m} \\
0 \\
0 \\
\dot{0} \\
1\end{array}$ & 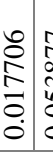 & 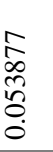 & 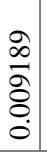 & 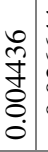 & 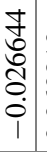 & 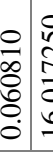 & & \begin{tabular}{l}
$m$ \\
\multirow{f}{f}{} \\
$\stackrel{8}{0}$
\end{tabular} \\
\hline 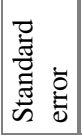 & & & 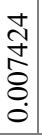 & 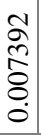 & 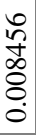 & & & & है & 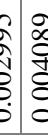 & \begin{tabular}{l}
$\infty$ \\
\hdashline \\
0 \\
8 \\
0 \\
0
\end{tabular} & $\begin{array}{l}1 \\
\delta \\
\delta \\
\delta \\
\tilde{8} \\
0\end{array}$ & $\begin{array}{l}\bar{\delta} \\
\delta \\
\tilde{\delta} \\
\tilde{\delta} \\
\dot{0}\end{array}$ & $\begin{array}{l}0 \\
\check{0} \\
0 \\
8 \\
0 \\
0\end{array}$ & 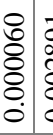 & 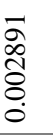 & 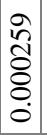 & $\begin{array}{l}\dot{t} \\
\tilde{8} \\
\delta \\
0 \\
0\end{array}$ & $\begin{array}{l}0 \\
= \\
\overline{8} \\
\delta \\
0 \\
0\end{array}$ & 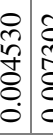 & & \\
\hline & & & 莘 & 菜 & 芩 & & & & 蒡 & 蒡 & 悉 & 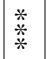 & 苂 & 蒾 & 善 & 蒾 & $\stackrel{*}{*}$ & $\begin{array}{l}\text { * } \\
* \\
*\end{array}$ & 芩 & * & & \\
\hline 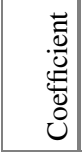 & & & $\begin{array}{l}\hat{a} \\
\dot{a} \\
o \\
+ \\
\dot{0} \\
1\end{array}$ & $\begin{array}{l}\stackrel{2}{\widehat{\lambda}} \\
\delta \\
0 \\
\\
0 \\
1\end{array}$ & 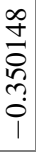 & & & & 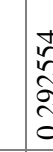 & 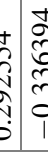 & 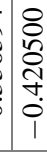 & $\begin{array}{l}m \\
\stackrel{0}{=} \\
\tilde{\sigma} \\
\dot{0}\end{array}$ & $\begin{array}{c}1 \\
\tilde{n} \\
2 \\
\delta \\
0 \\
0\end{array}$ & $\begin{array}{l}n \\
n \\
\infty \\
o \\
0 \\
0 \\
1\end{array}$ & 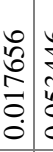 & 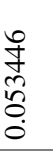 & $\begin{array}{l}8 \\
\frac{8}{2} \\
8 \\
0 \\
0\end{array}$ & 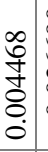 & $\begin{array}{l}0 \\
0 \\
0 \\
0 \\
0 \\
0 \\
1\end{array}$ & 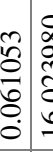 & & 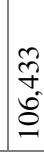 \\
\hline 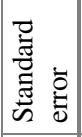 & $\begin{array}{l}8 \\
8 \\
\\
8 \\
8 \\
0 \\
0\end{array}$ & $\begin{array}{l}0 \\
\frac{1}{n} \\
\varnothing \\
0 \\
0\end{array}$ & & & & & & & ஓ̊ & 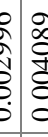 & $\begin{array}{l}\infty \\
0 \\
0 \\
0 \\
0 \\
0\end{array}$ & $\begin{array}{l}\bar{\delta} \\
\grave{2} \\
\overline{8} \\
\dot{0}\end{array}$ & 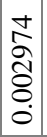 & $\begin{array}{l}0 \\
\tilde{0} \\
0 \\
8 \\
0 \\
0\end{array}$ & 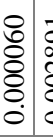 & 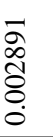 & 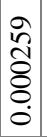 & $\begin{array}{l}\tilde{n} \\
\tilde{8} \\
\delta \\
\dot{0}\end{array}$ & 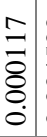 & 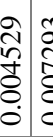 & 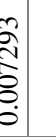 & \\
\hline & 耪 & 芩 & & & & & & & 蒚 & $\begin{array}{l}* \\
* \\
*\end{array}$ & $\begin{array}{l}\text { * } \\
* \\
*\end{array}$ & $\begin{array}{l}* \\
* \\
* \\
*\end{array}$ & $\begin{array}{l}* \\
* \\
*\end{array}$ & $\begin{array}{l}* \\
* \\
*\end{array}$ & 蒂 & 蒫 & 菜 & $\begin{array}{l}\text { * } \\
* \\
*\end{array}$ & $\begin{array}{l}\text { * } \\
* \\
*\end{array}$ & * & * & \\
\hline 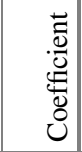 & 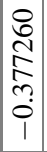 & 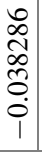 & & & & & & & $\frac{8}{2}$ & 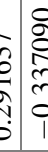 & 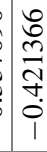 & $\begin{array}{c}n \\
n \\
\tilde{y} \\
\tilde{0} \\
\dot{0}\end{array}$ & 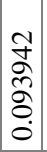 & $\begin{array}{l}\hat{0} \\
\text { ஸे } \\
\infty \\
0 \\
0 \\
0 \\
1\end{array}$ & 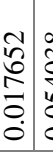 & $\begin{array}{l}\infty \\
\tilde{o} \\
\vdots \\
\vdots \\
0 \\
0\end{array}$ & \begin{tabular}{l}
$\hat{i}$ \\
\hdashline \\
$\hat{\delta}$ \\
0 \\
0
\end{tabular} & 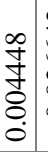 & $\begin{array}{l}0 \\
0 \\
0 \\
0 \\
0 \\
\dot{1} \\
1\end{array}$ & 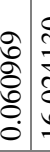 & 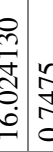 & $\begin{array}{l}\text { } \\
\stackrel{7}{f} \\
\stackrel{0}{\circ}\end{array}$ \\
\hline
\end{tabular}

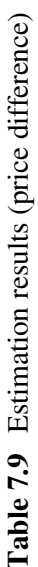

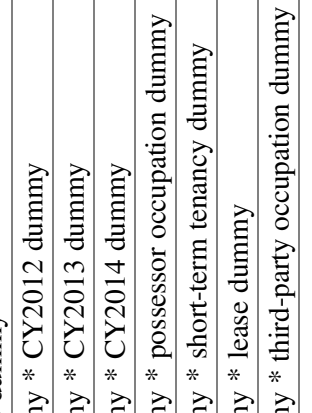

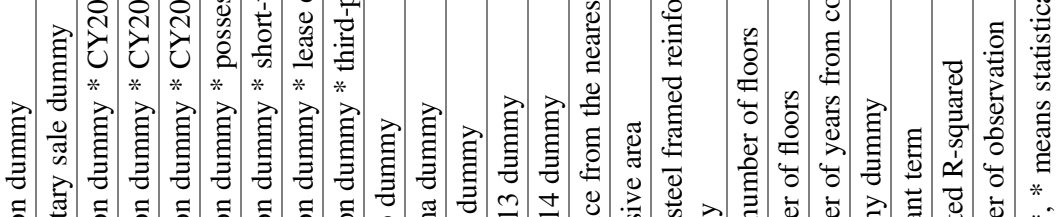

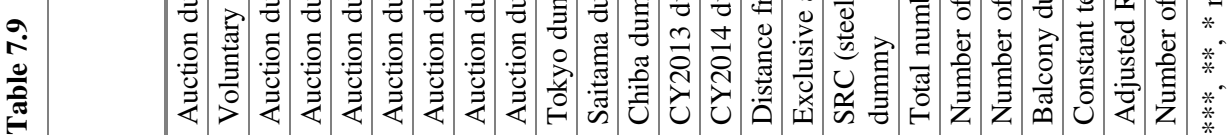




\subsection{Policy Proposals Concerning Revisions of the Court Auction System}

Empirical analysis identified that system revisions of the judicial real estate auctions had a positive impact on the bid acceptance ratio, etc. However, this also showed that the price difference remains large compared to general real estate trading and voluntary sales. Here, we project further facilitating of judicial real estate auctions and propose revisions to the judicial real estate auction system taking account of the results of the empirical analysis.

\subsubsection{Proposal Concerning the Resolution of Information Asymmetry for Auction Properties}

It is important for judicial real estate auctions to resolve the difficulty to ascertain precise value of the property to enable hopeful purchasers to bid according to an evaluation based on personal valuation of the auction property. Empirical analysis identified that the introduction of the Broadcast Information of Tri-set system had a positive impact on the bid acceptance ratio, etc. However, there appears to be scope for further system revisions as set out below.

\section{Expand the Data Listed in the Broadcast Information of Tri-set System}

In the Broadcast Information of Tri-set system, it is impossible to acquire a set of three types of information after a certain period has elapsed from the date of the successful bid. In addition, even for analysis of past auction data, the data that can be acquired are limited with only those of the past 3 years are available.

When investigating bidding, in addition to the fact that past successful bid data serve as useful reference, it is easy to acquire such information for general used real estate trades, so it would be best to enhance the data listed in relation to judicial real estate auctions, too, and provide information that is useful for judging bids.

\section{Improving the Preliminary Inspection Procedures}

There are restrictions on preliminary inspections of property for judicial real estate auctions. Under the Civil Execution Act, where a petition of the preliminary inspection is filed for the judicial real estate auction by the obligee (creditor) and the title to possession held by the possessor (occupant) may be duly asserted against the obligee affecting a foreclosure, the consent of such possessor is required. In addition, even in terms of the date of the preliminary inspection, the designation by the court following the petition may be inconvenient for the person hoping for a 
preliminary inspection, so there are currently very few cases of preliminary inspection (Ministry of Justice: Auction System Study Group 2008). It would be helpful to make it possible to have preliminary inspection on the application of hopeful purchasers as well as designating dates, times, and number of people for preliminary inspection in advance when announcing the auction taking account of the burden on the debtor side. In addition, new postings such as videos for hopeful purchasers that find it difficult to proceed in accordance with the preliminary inspection would also contribute to resolving the information asymmetry.

\subsubsection{Proposal for Lower Limit Price for Effective Bidding}

As noted in Sect. 7.4.2, bidding above the minimum purchase price is currently effective, but it is conceivable that this could be misused with anti-social occupants that would not place a value above such price that would impede a smooth auction. This system was introduced to prevent the obstruction from pressures exerted by anti-social forces and others under the previous bidding system (auction by hopeful purchasers) (Fukui 2006), but the purpose of its introduction has now been lost now with the introduction of the term bidding system.

As seen in the results of the empirical analysis, the revisions to the minimal sale price system had a positive impact on the bid acceptance ratio and highest bid, so a shift to a reference price system or setting a lower limit price for creditors is thought to contribute to a high successful bid. Consequently, there is scope to introduce a selective system that enables the adoption of a lower limit price system.

\subsubsection{Property Handover}

Under judicial real estate auctions, the ownership transfer is registered following payment of the proceeds by the purchaser, but the procedures for removing the occupant in the handover of the property must be handled by the purchaser him or herself. ${ }^{5}$ Based on the results of the empirical analysis of the abolition of protection of short-term tenancy, revision of the system is needed for the sake of reducing the burden to the purchaser in removing the occupant, and eliminating his or her misgivings about the auction property. For general real estate trading, ownership

\footnotetext{
${ }^{5}$ If it is $<6$ months from a day of the price payment, there is the system of the delivery order that a court of execution can command to deliver auction real estate to the purchaser for the occupant by the statement of purchaser (Civil Execution Act (1979 law 4th) Article 83 Clause 1). It is the procedure that is simpler than normal suit, but the statement of the delivery order is necessary, and advance payment to be necessary for the statement and the compulsory execution when carrying out compulsory execution of delivery after the delivery order decided. So, it is a burden on the purchaser at certain level.
} 
transfer and handover occur at the same time. Given that real estate operators are also involved in the mediation, the handover goes smoothly. Consequently, it is also desirable for judicial real estate auctions that the court implements the confirmation of the state of occupancy following a successful bid and ensures the transfer of ownership to the purchaser and the property handover take place simultaneously to reduce the burden on the purchaser.

In addition, for judicial real estate auction there is no defect liability concerning the quality of the property. In the 2013 interim plan of the Legislative Council (Committee of the Civil Law), there was a proposal to amend the provisions of the Civil Code, and to apply a rule of defect liability in relation to judicial real estate auctions as well (Ministry of Justice: Legislative Council (Committee of the Civil Low (obligation)) The 71st Meeting 2013). However, in the subsequent public comment procedures, there was opposition to the revisions from various quarters (Ministry of Justice: Legislative Council (Committee of the Civil Low (obligation)) The 80th Meeting 2013), saying that, given the imperfections in property information disclosure, the results of auction procedures would be often overruled, etc.; as a result, the implementation of 2017 revisions to the Civil Code has been postponed. ${ }^{6}$ Consequently, the introduction of defect liability to judicial real estate auctions should be investigated as a measure to resolve the asymmetry of property information.

\subsection{Conclusion}

The large price difference between judicial real estate auctions and voluntary sales was identified by empirical analysis, but even if the background to the sale had the same cause being the recovery of a claim, this means the economic value of the property was determined to be lower with a judicial real estate auction. This can also be expressed as stating that the debtor suffered a loss at that point.

There are outstanding issues for the judicial real estate auction system as mentioned in Sect. 7.7, but since this issue can be considered one of the causes for the price difference, a reduction in the price difference should be possible through system revisions that resolve this issue. The ability to sell at a high price through judicial real estate auction creates profit not only for the creditor but also the debtor. In addition, active provision of property information is desirable for purchasers. Furthermore, by reducing the defect risk for creditors and lowering the cost of financing will lead to lower interest rates and increase lending volumes in the financial markets, which stimulates the entire economy.

Since this type of system revision is anticipated to have wide-ranging impact, opinions should be collected from a wide range of persons. Nevertheless, as also

\footnotetext{
${ }^{6}$ In Civil Law (1896 law 89th) Article 568 Clause 4 after the revision by the Law (2017 law 44th) to revise a part of the Civil Law, warranty does not arise about the quality of the auction is prescribed.
} 
noted by the Regulatory Reform Council in the Cabinet Office, hearings like those conducted at the Auction System Study Group by the Ministry of Justice tend to have a bias toward the opinions of certain stakeholders, and it will be impossible to obtain a distribution of opinions for all the industries and people related to judicial real estate auctions without an all-encompassing questionnaire survey (Cabinet Office: Regulatory Reform Council 2007). It is also the role of policy makers to make judgment by scrutinizing opinions and to make decisions based on clear reasons of why a matter is considered appropriate, and this should lead to a judicial real estate auction system that is desirable for society as a whole.

\subsection{Future Issues}

This paper conducted analysis that was restricted to auctions that occurred in 1 metropolitan area and 3 prefectures from the perspective of data constraint, but since judicial real estate auction is a system that has been introduced nationwide in Japan, it would be desirable to conduct analysis that is more precise and covering a wider scope.

In addition, this paper focuses on the price difference looking at difference in the transaction system for the price difference between auctioned properties and general real estate properties, but the price difference is also determined by quality differences and the difference of the potential number of purchasers at the time of the transaction. The analysis in this paper has not been able to distinguish main causes other than the difference in transaction systems, and participants in judicial real estate auction also include operators that plan to on-sell or lend the property so there are questions concerning the ability to compare with the general real estate market. These are limitations of the analysis in this paper.

In addition, in analysis of the impact of auction system revisions, there was an attempt to control the main causes of economic change, but it is possible that they could not be completely controlled. Conducting analysis that compares auction data and general real estate trading data for the same fiscal year would likely be more precise. A future issue will be to conduct more detailed and precise analysis using such data.

Acknowledgments The points of view in this paper are based on the results of research undertaken when the author was at the National Graduate Institute for Policy Studies Urban Policy Program and are the personal opinions of the author. The author does not represent that these views are those of the institution to which he was affiliated. 


\section{References}

Cabinet Office (2007) Investigation about the improvement policy of judicial real estate auction system questionnaire findings summary for Associated supplier, scholar of specialized qualification [Translated from Japanese]. pp 3-4. http://www8.cao.go.jp/kisei-kaikaku/publication/ 2007/1220/item071220_02.pdf

Cabinet Office: Regulatory Reform Council (2007) The second report for regulation reform promotion [Translated from Japanese]. p 50. http://www8.cao.go.jp/kisei-kaikaku/publication/ 2007/1225/item071225_02.pdf

Fukui H (2006) Shihou seisaku no hou to keizaigaku [Law and economics of the judiciary policy]. Nippon Hyoron Sha, Tokyo, pp 106-110

Fukui H (2007) Keesu kara hajimeyou hou to keizaigaku [Let's begin with the case -law and economics-]. Nippon Hyoron Sha, Tokyo, pp 108-110

Fukui H, Kume Y (2015a) Economic assessment of the influence that the abolition of the protection of short-term tenancy (2003 law revision) gave for the judicial real estate auction market [Translated from Japanese]. Evaluation 58:71-84

Fukui H, Kume Y (2015b) The influence that the protection of short-term tenancy (before the system revision) gave to the highest bid [Translated from Japanese]. J Prop Assess Policy 16 (2 (consecutive number of vol. 29)):22-30

Hoshino T, Nakanishi H (2016) Economic valuation of environmental quality using property auction data: a structural estimation approach. Land Econ 92(4):703-717

Idee T, Iwata S, Taguchi T (2011) Auction price formation with costly occupants: evidence using data from the Osaka district court. J Real Estate Financ Econ 42(1):84-98

Kazumi A (2014) The influence that the provision of information about the properties gives to the highest bid and number of bidders on judicial real estate auction: empirical analysis on the effect by the use of judicial real estate auction properties information site [Translated from Japanese]. Master's thesis of the National Graduate Institute for Policy Studies Urban Policy Program

Maruoka K (2011) The influence that the third party occupation gives for the judicial real estate auction market: empirical analysis on the abolition of protection of short-term tenancy and the suspension of delivery system [Translated from Japanese]. Master's thesis of the National Graduate Institute for Policy Studies Urban Policy Program

Ministry of Justice: Auction System Study Group (2007) 18th Summary of the proceedings [Translated from Japanese]. pp 35-38. http://www.moj.go.jp/content/000011266.pdf

Ministry of Justice: Auction System Study Group (2008) The main body of report [Translated from Japanese]. pp 56-57. http://www.moj.go.jp/content/000011278.pdf

Ministry of Justice: Legislative Council (Committee of the Civil Low (obligation)) The 71st Meeting (2013) Middle tentative plan about the revision of Civil Low (obligation) [Translated from Japanese]. pp 61-62. http://www.moj.go.jp/content/000108218.pdf

Ministry of Justice: Legislative Council (Committee of the Civil Low (obligation)) The 80th Meeting (2013) Meeting document 71-6 summary of sent opinion for "middle tentative plan about the revision of Civil Low (obligation) (detailed explanation 5) [Translated from Japanese]. pp 36-43. http://www.moj.go.jp/content/000119459.pdf

Taguchi T, Ide T (2004) Bad loans and the role of minimum prices in real estate auctions: an empirical analysis from Osaka. Jpn J Real Estate Sci 17(3):91-99

Takahashi O (2015) Influence on bid acceptance ratio and highest bid by the minimal sale price system revision of judicial real estate auction [Translated from Japanese]. Master's thesis of the National Graduate Institute for Policy Studies Urban Policy Program

Yamamoto I (2015) Jisshou bunseki no tame no keiryou Keizaigaku tadashii shuhou to kekka no yomikata [Econometrics for empirical analysis]. Chuokeizai Sha, Tokyo, pp 134-143 
Open Access This chapter is licensed under the terms of the Creative Commons Attribution 4.0 International License (http://creativecommons.org/licenses/by/4.0/), which permits use, sharing, adaptation, distribution and reproduction in any medium or format, as long as you give appropriate credit to the original author(s) and the source, provide a link to the Creative Commons licence and indicate if changes were made.

The images or other third party material in this chapter are included in the chapter's Creative Commons licence, unless indicated otherwise in a credit line to the material. If material is not included in the chapter's Creative Commons licence and your intended use is not permitted by statutory regulation or exceeds the permitted use, you will need to obtain permission directly from the copyright holder. 